\title{
ASSESSMENT OF THE FUNCTIONING OF FARMS IN LESS-FAVORED AREAS AND IN AREAS OF SIGNIFICANT NATURAL VALUE (LFA SPECIFIC TYPE ZONE I)*
}

\author{
MAREK ZIELIŃSKI \\ ARTUR ŁOPATKA \\ PIOTR KOZA
}

\begin{abstract}
The purpose of this study is to characterize municipalities with a high share of LFAs (specific type zone I) as well as to assess the functioning of farms located in such municipalities against the background of analogous farms in non-LFA municipalities which kept accounts for the Polish FADN continuously in 20162018. The first part of the study describes the method of determining and characterizing areas with natural constraints (LFA) of specific type located in zone I in Poland designated by the Institute of Soil Science and Plant Cultivation - NRI (IUNG-PIB) on behalf of the Ministry of Agriculture and Rural Development (MRiRW) and the European Commission (EC). These areas were determined on the basis of the threshold values of the Nature and Tourism Index (WCPT) and the Index for the Valorisation of Agricultural Production Area (WWRPP). They have functioned in our country since 2019 and include 1233,7 thousand ha UAA. The second part of the study presents the functioning of farms located
\end{abstract}

\footnotetext{
* Elaborated within the framework of the task entitled Evaluation of the Activity of Farms Serving Better Environmental and Climate Protection protection IERiGŻ-PIB for 2020 and the task entitled Development and Improvement of Methods and Instruments Useful for Shaping the Impact of the Cap on the Natural Environment IUNG-PIB for 2016-2020.
}

Marek Zieliński, DEng, Institute of Agricultural and Food Economics - National Research Institute, Department of Economics of Agricultural and Horticultural Holdings; ul. Świętokrzyska 20, 00-002 Warsaw, Poland (marek.zielinski@ierigz.waw.pl). ORCID iD: 0000-0002-6686-5539. Artur Łopatka, MSc, Institute of Soil Science and Plant Cultivation - State Research Institute, Department of Soil Science Erosion and Land Conservation; ul. Czartoryskich 8, 24-100 Puławy, Poland (artur@iung.pulawy.pl). ORCID iD: 0000-0002-6977-4464.

Piotr Koza, MSc, Institute of Soil Science and Plant Cultivation - State Research Institute, Department of Soil Science Erosion and Land Conservation; ul. Czartoryskich 8, 24-100 Puławy, Poland (pkoza@iung.pulawy.pl@iung.pulawy.pl). ORCID iD: 0000-0002-0243-7631. 
in municipalities with a high share of LFAs (specific type zone I) (at least $80 \%$ UAA LFA specific type zone 1 in total UAA) against the background of analogous farms in non-LFA municipalities that kept accounts for the Polish FADN continuously in 2016-2018. It was found that farms located in LFAs are characterized by lower capital value, older farm owners, and poorer quality of used soils. In addition, they incur lower costs per 1 ha of UAA, have worse production effects and lower factor productivity. Moreover, they have lower income per 1 ha of UAA, and thus smaller development opportunities.

Keywords: LFA specific type zone I, nature value, farm, potential of production, economic situation.

JEL codes: Q12, Q15, Q57.

\section{Introduction}

Regulation (EU) No 1305/2013 of the European Parliament and of the Council of 17 December 2013 on support for rural development by the European Agricultural Fund for Rural Development (EAFRD) and repealing the Council Regulation (EC) No 1698/2005 sets out a new approach to the designation (delimitation) of areas facing natural constraints in the European Union (EU). According to this Regulation, the new delimitation of areas with natural constraints was carried out in all EU Member States in accordance with uniform biophysical criteria relating to climate quality, soil characteristics and inclination of the land, and was based on data of a similar accuracy (Regulation No. 1305/2013 of the European Parliament and of the Council; JRC, 2016). At the same time, a mandatory step in this delimitation was the fine-tuning process consisting in excluding from the support those areas with natural constraints, "(...) in which significant natural constraints have been documented, but have been overcome by investments or by economic activity, or by evidence of normal land productivity, or in which production methods or farming systems have offset the income loss or added costs (...)". (Regulation No. 1305/2013 of the European Parliament and of the Council; EC 2016). In Poland, spatial analyses related to the presence of natural constraints defined by the biophysical criteria set out in Regulation No 1305/2013 have been performed by the Institute of Soil Science and Plant Cultivation - National Research Institute in Puławy (IUNG-PIB) in cooperation with the National Chemical and Agricultural Station as well as the District Chemical and Agricultural Stations, which collected and analysed samples for the purpose of making soil pH maps (Raport..., 2018). The Institute of Agricultural and Food Economics - National Research Institute in Warsaw (IERiGŻ-PIB) (Opis..., 2017; Zieliński, 2018) was responsible for works related to the fine-tuning procedure.

Taking into account the above circumstances, in Poland, in 2019, payments to less-favored areas (LFA) in lowland areas (LFA types I and II) under the CAP 2014-2020 were replaced by payments for areas with natural constraints or with other spe- 
cific constraints ${ }^{1}$. As a result, some new LFAs have been designated in our country in lowland areas: LFA zone with natural constraints types I and II (representing 28.5 and $18.5 \%$ of the UAA in Poland, respectively) and additionally LFA specific type zone I characterised by high natural value ( $7.0 \%$ of the UAA in Poland) (Lopatka, Koza and Siebielec, 2017, Raport..., 2018, MRiRW 2018)2. It should also be mentioned that, as part of the works on the new delimitation of LFAs, LFA specific type zone II was updated, covering mainly submontane areas $(3.0 \%$ of the UAA in Poland) and LFAs of mountain type (1.7\% of UAA in Poland) (Figure 1). In Poland, all five LFA zones have been delimited at the level of municipalities and surveying districts (MRiRW, 2018; Zieliński and Sobierajewska, 2020).

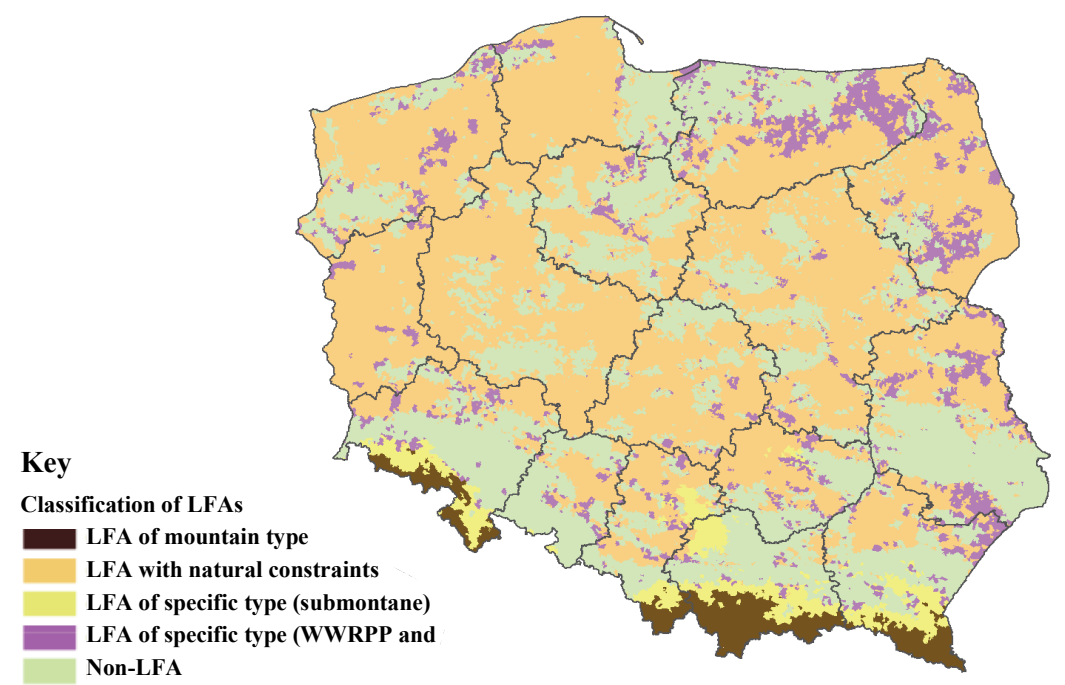

Fig. 1. Range of areas meeting the current LFA criteria.

Source: own study.

The aim of this study is to characterise municipalities with a high share of LFA of specific type in zone I and evaluate the functioning of farms in these municipalities against the background of analogous farms in non-LFA municipalities, which kept accounts for the Polish FADN continuously in 2016-2018. This comparison aims to evaluate whether and to what extent the areas of high nature value and with dispersed production having at the same time difficult natural conditions for agricultural production, influence the possibilities of duration and development of farms located on their territory.

\footnotetext{
${ }^{1}$ Previous lowland LFA zones (before 2019) were designated in each EU country according to criteria developed locally; in Poland with the use of the valorisation index of agricultural production space (WWRPP) which mainly characterises soil quality and population density (Raport.., 2018).

${ }^{2}$ It should be stressed that the delimitation of LFA of specific type in zone I is a conceptual and, to some extent, prevalent continuation of the existing lowland LFA located in zone I, including areas of high natural value. Works on delimitation of LFAs of specific type in zone I have been carried out in IUNG-PIB in Puławy since 2012. (under Tasks 2.1 and 1.9 of the IUNG-PIB Multiannual Programmes for years 2011-2015 and 2016-2020, respectively).
} 


\section{Research method}

At the IUNG-PIB, in order to designate LFA of specific type in zone I in Poland, an integrated index was developed which is an easy method to interpret function of several measures of the extent to which natural constrictions affect the distance between fields, farms and markets (Łopatka et al., 2017). This index was named the Nature and Tourism Value Index (WCPT) and was generally defined as the share of the total area of permanent grasslands (TUZ), forests, waters (inland and sea waters) and other areas not subject to anthropopressure in the total area. In regions with areas of a high nature value and areas which are attractive to tourists, maintaining agricultural production is particularly difficult due to spatial dispersion of arable land and associated higher transport costs (e.g. Dudzińska, 2011; Juroszek, 2011; Prishchepov, Müller, Dubinin, Baumann and Radeloff, 2013; Kołodziejczak, Głębocki, Kacprzak, Maćkiewicz and Szczepańska, 2019). In free market conditions, this leads to reduced competitiveness and disappearance of infrastructure related to procuring and processing of agricultural products.

Determining the area in relation to which the share of these areas is calculated is disputable. This should not be the total area of an administrative unit due to the heterogeneous size of administrative units and the difficulty of taking into account the synergistic effects resulting from the vicinity of the valuable nature areas in neighbouring units. From the environmental point of view, the value of the area is dictated not only by the local valuable habitats, but also by possible migration of animals and plants between not too distant habitats. This increases the available genetic pool of the environment and makes it resistant to local threats. This effect was taken into account in the preliminary delimitation of the high nature value (HNV) areas carried out in 2009. In Poland, this delimitation was done by calculating the share of the high nature value areas within a $2 \mathrm{~km}$ radius (Wstepna koncepcja..., 2009). Taking into account a wider space is also justified from the point of view of visual and, consequently, touristic attractiveness of the area. The method of analysing the surroundings within a $2 \mathrm{~km}$ radius additionally ensures that the Baltic Sea, the waters of which are not included in the area of administrative units, but their inclusion is particularly important due to the requirement to preserve the tourist potential or protect the coastline, is included in the delimitation.

In the Chief Sanitary Inspectorate (GIS) software, the analysis of calculating the shares of valuable natural areas is performed by the use of the so-called "movable window" method. It means that the program moves a window of a given shape cell by cell across a raster land use map, adds up the number of cells of a selected usage and assigns the result to the UAA cell lying in the centre of the window on a new raster layer. Due to the fact that we are looking for constraints for agricultural production, the result layers of the movable window analyses (i.e. calculations of average values of the index and its components) are limited only to the UAA range. For this reason, the actual shares (e.g. of forests) in large administrative units (provinces, countries) are usually larger than the average shares of forests added up 
in the movable window, the centre of which always lies on UAA and therefore its area does not include the centres of large forest complexes. For small administrative units (districts), the movable window may include, for example, forests from neighbouring administrative units, so their average share in the movable window may be larger than the share in a given unit. This means that in extreme cases it is possible to assign a high share of areas of natural and touristic value to a small administrative unit, even if there is no such area in a given unit (an agricultural district being a "clearing" in a large forest complex). However, this does not undermine the legitimacy of the proposed method, but it is only a striking example of a situation in which the administrative boundaries are not appropriate for assessing constraints on agricultural production and in which the proposed method correctly evaluates these constraints regardless of the course of administrative boundaries. Calculations with the use of the movable window method within a radius of $2 \mathrm{~km}$ were performed on a raster layer of the land use with a resolution of $10 \mathrm{~m}$, created on the basis of a soil-agricultural map updated on the basis of the land use fields in the scale 1:25,000. As previously indicated, forest complexes, permanent grasslands (TUZ), waters and other areas with a low degree of anthropogenic transformation (trees, wetlands and other areas unsuitable for agricultural production) were regarded as valuable areas. The average share of valuable areas added up in this way was $35.6 \%$ of the land area in the country, with forests and permanent grasslands dominating, constituting $16.7 \%$ and $14.7 \%$, respectively.

Ultimately, LFA of specific type in zone I was separated using a combination of the WCPT index and the WWRPP index in accordance with the definition adopted in the EU and its interpretation developed for the Poland's conditions, as well as with the arrangements with the Ministry of Agriculture and Rural Development,. It was assumed that the worse the valorisation of the production space, the less restrictive the threshold values of the WCPT index (Table 1). In Poland, the current LFA of specific type in zone I covers 1233.7 thousand ha of UAA and the areas are located in 600 municipalities ${ }^{3}$ with an average UAA size of about 8.5 thousand ha and an average farm area of 13.2 ha of UAA.

Table 1

Criteria for qualification of administrative units (municipalities and surveying districts) to LFA specific type zone I

\begin{tabular}{cccc}
\hline \multirow{2}{*}{ WCPT $^{\mathrm{a}}$ (points) } & \multicolumn{3}{c}{ WWRPP $^{\mathrm{b}}$ (points) } \\
\cline { 2 - 4 } & $52-66$ & $66-72.5$ & $>72.5$ \\
\hline $35.6-53.4$ & LFA spec. type I & Lack of LFA spec. type I \\
\hline$>53.4$ & \multicolumn{2}{c}{ LFA spec. type I } & Lack of LFA spec. type I \\
\hline
\end{tabular}

a an average for Poland $-35.6 ;{ }^{b}$ an average for Poland - 66.6.

Source: own study on the basis of information from the MRiRW (Program..., 2018).

${ }^{3}$ In Poland, UAA of LFA of specific type in zone I are located in 600 municipalities and 2935 surveying districts. 
In order to achieve the objective of the study, three groups of farms of the same production type, which kept accounts for the Polish FADN continuously between 2016 and 2018, were distinguished from municipalities with at least $80 \%$ of UAA LFA in UAA, hereinafter referred to as municipalities with a high share of LFA of specific type in zone I, and from non-LFA municipalities (other municipalities) and subsequently a comparative analysis was conducted ${ }^{4}$. Among the farms from municipalities with a high share of LFA of specific type in zone I and other municipalities, 79 and 589 farms with field crops (type 1), 59 and 89 keeping dairy cows (type 45), and 42 and 272 farms with diversified production (type 8) were identified, respectively ${ }^{5}$. Therefore, the analysis included production types of farms of high importance in Polish agriculture (GUS, 2017). The following characteristics were subject to comparative analysis:

1) production potential:

- UAA (ha),

- percentage of rented land in the UAA (\%),

- soil bonitation index (point),

- total labour input per farm expressed in Annual Work Units (one work unit expressed in AWU corresponds to 2120 hours),

- labour input of a farmer and their family members expressed in Family Work Units (one work unit expressed in FWU corresponds to 2120 hours),

- age of farm managers (years),

- capital value, including the value of agricultural machinery and equipment (PLN thousand);

2) production organisation:

- percentage of grains in UAA (\%),

- percentage of fodder crops in UAA (\%),

- stocking density expressed in head count per 1 ha of UAA (LU/ha UAA);

3) production effects, productivity, economic efficiency and development opportunities:

- wheat yield (dt/ha),

- corn yield (dt/ha),

- milk yield of cows (kg/cow/year),

- land productivity (PLN/ha UAA) determined as the relation of the total production value in the farm to the UAA,

- labour productivity (PLN/AWU) determined as a relation of total production value to the number of full-time employees,

- income from an agricultural farm per 1 ha of UAA (PLN thousand),

- income from own work of a farmer and his family members per 1 FWU (PLN thousand),

\footnotetext{
${ }^{4}$ The analysis used the most up-to-date data of the Polish FADN.

${ }^{5}$ Production types of farms were determined based on the method of their delimitation applied by the Polish FADN (Wyniki standardowe..., 2019).
} 
- net investment rate $(\%)$ defined as the ratio of net investment to depreciation,

- debt rate $(\%)$ defined as the ratio of the short, medium and long term loans to the principal value.

\section{Characteristics of municipalities with a high share of LFA specific type zone I compared to non-LFA municipalities}

According to the current delimitation of LFAs, in Poland there are 600 municipalities with UAA LFA of specific type I, of which 36 have at least $80 \%$ of UAA (municipalities with a high share of LFA of specific type in zone I) ${ }^{6}$, and 343 nonLFA municipalities(Fig. 2 and 3) 7 .

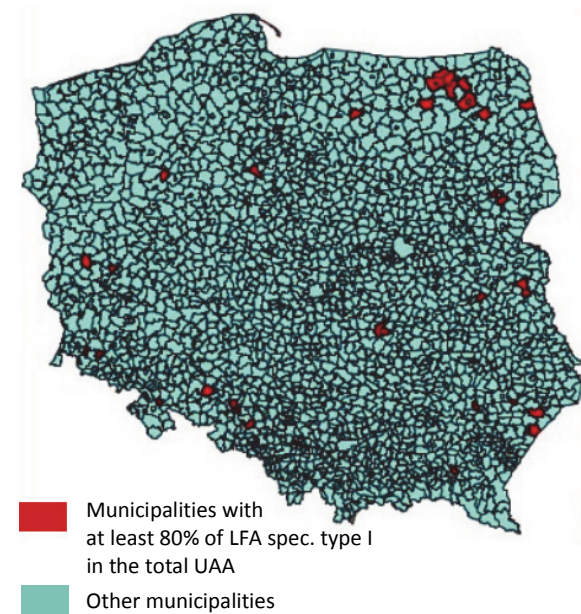

Fig. 2. Municipalities with a high share of LFA specific type zone I.

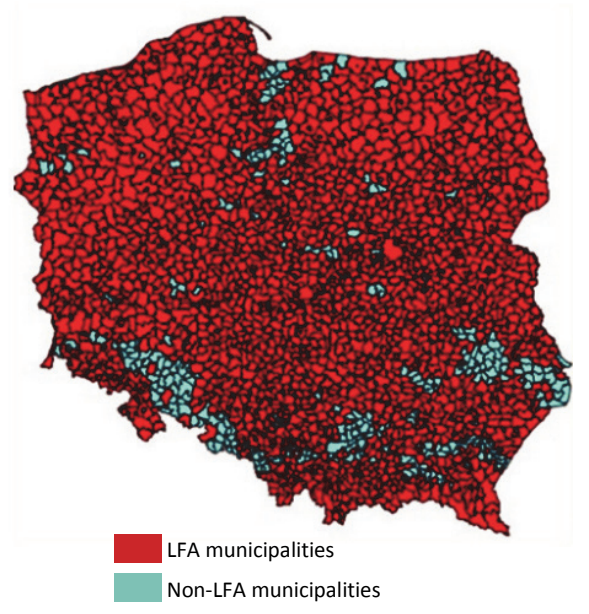

Fig. 3. Non-LFA municipalities.

Source: own study.

In municipalities with a high share of LFA specific type zone I, the average UAA of farms is 12.7 ha, ranging from 3.6 ha (Municipality of Korczyna, Podkarpackie Province) to 24.5 ha (Municipality of Gietrzwałd, Warmińsko-Mazurskie Province). However, this situation is quite different in municipalities which serve as a reference point. In these municipalities, the average area of a farm is 11.7 ha and ranges from 2.3 ha (Municipality of Radlin, Silesia Province) to $48.3 \mathrm{ha} \mathrm{(Mu-}$ nicipality of Banie, Zachodniopomorskie Province). It should also be noted that the average area of a farm in Poland is 10.3 ha, and in total municipalities it ranges

\footnotetext{
${ }^{6}$ In four municipalities in Poland, the percentage of UAA qualified as LFA specific type zone I in relation to the surface of UAA is at least $99 \%$.

${ }^{7}$ According to data of the Polish FADN for 2016-2018, there were farms from 33 municipalities with at least $80 \%$ of UAA LFA specific type zone I in UAA and 308 non-LFA municipalities .
} 
from 2.0 (Municipality of Krupski Młyn, Śląskie Province) to 59.0 ha (Municipality of Dobra, Zachodniopomorskie Province) ${ }^{8}$ (Fig. 4 and 5) (ARiMR database for 2017; GUS, 2017).

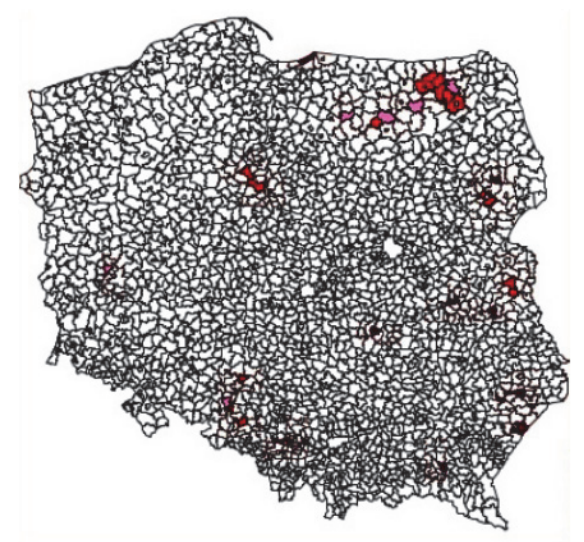

Municipalities with at least $80 \%$ of UAA LFA spec. type I in the total UAA and with the average UAA of farms:

Less than 10 ha

10-20 ha

More than 20 ha

Fig. 4. Municipalities with a high share of LFA specific type I according to the average area of farms.

Source: own study based on the IUNG-PIB data.

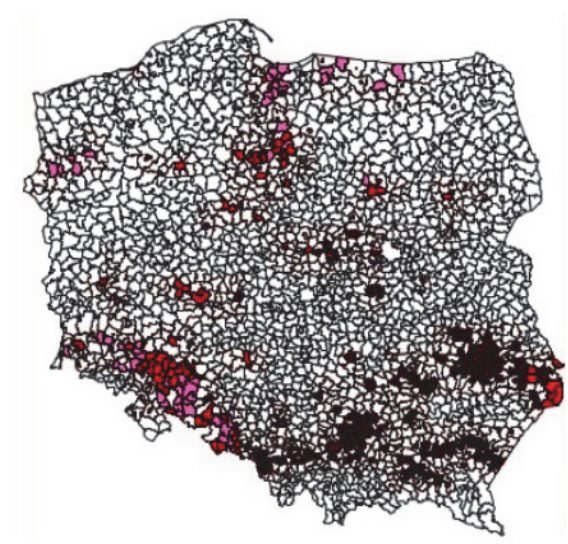

Municipalities without the LFA UAA and with the average UAA of farms:

Less than 10 ha
10-20 ha
More than 20 ha

Fig. 5. Non-LFA municipalities according to the average area of farms.

Municipalities with a high share of LFA specific type zone I clearly differ from non-LFA municipalities in terms of the natural conditions of agricultural production and the areas of high nature value.

In Poland, the average WWRPP ${ }^{9}$ index is 66.6 out of possible 120 points. In this respect, the municipalities with a high share of LFA specific type zone I are in a disadvantaged position. In their case, the average WWRPP index is 62.8 points, of which $97.2 \%$ is lower than the national average, which means that these are areas with UAA with difficult conditions for agricultural production. In the municipalities which are a reference point, the situation is much better. In these municipalities, the average WWRPP index is 85.6 points, and the share of municipalities with the WWRPP of at least 95 points is $22.2 \%$. It should also be mentioned that in Poland, the largest WWRPP index is 108.3 points is held by Municipality of

\footnotetext{
${ }^{8}$ Data on the average UAA of farms in municipalities in Poland were derived from the ARiMR database on agricultural holdings of direct payment beneficiaries for 2017.

${ }^{9}$ The WWRPP index takes into account the factors influencing the quality of natural economic conditions such as: quality and usefulness of soils, water conditions, topography and agroclimate. Each of them has been assigned a weight proportional to its impact on the crop yield (GUS, 2013).
} 
Żurawina (Dolnośląskie Province). In Poland, the average WCPT index is 35.6 out of possible 100 points. In the municipalities with a high share of LFA specific type zone I, the index is significantly higher and equals 48.6 points on average. The municipality with the highest value of this index is Municipality of Krynica Morska (70.8 points). It should be noted that in this respect, non-LFA municipalities are in a worse situation, as this index is 21.3 points on average.

\section{Characteristics of the analysed farms located in municipalities with a high share of LFA specific type zone I compared to farms located in non-LFA municipalities on the basis of the Polish FADN data for 2016-2018}

The area of agricultural land in the case of farms with dairy cows and diversified production in municipalities with a high share of LFA specific type zone I was higher compared to the area of similar farms located in non-LFA municipalities by 2.1 and $20.2 \%$, respectively. On the other hand, in the case of farms with field crops it was almost identical. It should be emphasized that farms located in municipalities with a high share of LFA specific type zone I, regardless of the analysed production type, were characterised by significantly worse quality of soils. This is evidenced by their significantly lower soil bonitation index (WBG). As for the percentage of leased land in UAA, farms with dairy cows and diversified production from municipalities with a high share of LFA specific type zone I had a slightly lower percentage by 3.6 and 2.9 percentage points, respectively. However, the percentage was higher in the case of farms with field crops by 5.7 percentage points (Table 2).

The labour input incurred in farms with field crops from municipalities with a high share of LFA specific type zone I was higher than in the remaining analogous farms by $2.3 \%$. On the other hand, in the case of farms with dairy cows and diversified production in LFA, they were lower by 5.4 and $7.6 \%$, respectively. It should also be noted that the farms located in municipalities with a high share of LFA specific type zone I, regardless of the analysed production type, had a greater own labour input in the total labour input as well as older age of their managers. Moreover, they had a smaller capital value, including a smaller value of agricultural machinery and equipment. As a consequence, this resulted in poorer technical equipment (relation of the capital value to the total labour input incurred) (Table 2). 
Table 2

Production potential of the analysed farms located in municipalities with a high share of LFA specific type zone I and in non-LFA municipalities which differ in terms of production type in 2016-2018

\begin{tabular}{|c|c|c|c|c|c|c|c|}
\hline \multirow{3}{*}{ Variable } & \multirow{3}{*}{ Unit } & \multicolumn{6}{|c|}{ Farms } \\
\hline & & \multicolumn{3}{|c|}{$\begin{array}{l}\text { in municipalities with at least } \\
80 \% \text { of LFA specific type zone I } \\
\text { in UAA }\end{array}$} & \multicolumn{3}{|c|}{ in non-LFA municipalities } \\
\hline & & $\begin{array}{l}\text { with field } \\
\text { crops }\end{array}$ & $\begin{array}{l}\text { with dairy } \\
\text { cows }\end{array}$ & $\begin{array}{l}\text { with } \\
\text { diversified } \\
\text { production }\end{array}$ & $\begin{array}{l}\text { with field } \\
\text { crops }\end{array}$ & $\begin{array}{l}\text { with dairy } \\
\text { cows }\end{array}$ & $\begin{array}{l}\text { with } \\
\text { diversified } \\
\text { production }\end{array}$ \\
\hline $\begin{array}{l}\text { Utilised agricultural } \\
\text { area }\end{array}$ & ha & 50.6 & 34.4 & 39.2 & 50.0 & 33.7 & 32.6 \\
\hline $\begin{array}{l}\text { - including leased } \\
\text { land }\end{array}$ & $\%$ & 36.7 & 28.5 & 26.9 & 31.0 & 32.1 & 29.8 \\
\hline $\begin{array}{l}\text { Soil bonitation index } \\
\text { (WBG) }\end{array}$ & points & 0.75 & 0.60 & 0.79 & 1.27 & 1.10 & 1.20 \\
\hline $\begin{array}{l}\text { Total labour input } \\
\text { per farm }\end{array}$ & AWU & 1.75 & 2.12 & 1.70 & 1.71 & 2.24 & 1.84 \\
\hline $\begin{array}{l}\text { - including own } \\
\text { labour }\end{array}$ & $\%$ & 88.6 & 96.2 & 97.1 & 81.9 & 87.5 & 86.9 \\
\hline $\begin{array}{l}\text { Age of the farm } \\
\text { manager }\end{array}$ & years & 46.1 & 46.2 & 45.3 & 43.4 & 43.8 & 44.9 \\
\hline Capital value & $\begin{array}{l}\text { PLN } \\
\text { thousand }\end{array}$ & 529.3 & 819.2 & 549.6 & 655.7 & 1039.6 & 633.0 \\
\hline $\begin{array}{l}\text { - including the value } \\
\text { of machinery and } \\
\text { equipment }\end{array}$ & $\begin{array}{l}\text { PLN } \\
\text { thousand }\end{array}$ & 254.7 & 269.1 & 183.5 & 312.2 & 347.1 & 225.6 \\
\hline
\end{tabular}

Source: own study based on the Polish FADN data.

The analysis of production organisation shows that in the case of farms with dairy cows and diversified production from the municipalities with a high share of LFA specific type zone I, grains had a smaller percentage in UAA compared to similar farms of the region. On the other hand, almost identical percentage of grains in UAA was observed in the case of farms with field crops (Table 3).

Farms with dairy cows and diversified production located in municipalities with LFA specific type zone I were characterised by a higher percentage of fodder crops in UAA and a lower stocking density of livestock in comparison with other analogous farms. Therefore, it cannot be ruled out that farms located in non-LFA municipalities despite more favourable conditions for growing fodder crops, used purchased fodder to a greater extent in livestock farming. It should also be added that in farms with field crops, in both compared groups, there was a small share of fodder crops in UAA and a trace density of livestock, which probably limited their ability to balance organic matter in the soil. 
Table 3

Organisation of production in the case of analysed farms located in municipalities with a high share of LFA specific type zone I and in non-LFA municipalities which differ in terms of production type in 2016-2018

\begin{tabular}{|c|c|c|c|c|c|c|c|}
\hline \multirow{3}{*}{ Variable } & \multirow{3}{*}{ Unit } & \multicolumn{6}{|c|}{ Farms } \\
\hline & & \multicolumn{3}{|c|}{$\begin{array}{l}\text { in municipalities with at least } 80 \% \\
\text { of LFA specific type zone I in UAA }\end{array}$} & \multicolumn{3}{|c|}{ in non-LFA municipalities } \\
\hline & & $\begin{array}{l}\text { with field } \\
\text { crops }\end{array}$ & $\begin{array}{l}\text { with dairy } \\
\text { cows }\end{array}$ & $\begin{array}{c}\text { with } \\
\text { diversified } \\
\text { production }\end{array}$ & $\begin{array}{l}\text { with field } \\
\text { crops }\end{array}$ & $\begin{array}{l}\text { with dairy } \\
\text { cows }\end{array}$ & $\begin{array}{c}\text { with } \\
\text { diversified } \\
\text { production }\end{array}$ \\
\hline $\begin{array}{l}\text { Percentage of } \\
\text { grains in UAA }\end{array}$ & $\%$ & 62.1 & 17.4 & 59.0 & 62.0 & 33.0 & 62.4 \\
\hline $\begin{array}{l}\text { Percentage of } \\
\text { fodder crops } \\
\text { in UAA }\end{array}$ & $\%$ & 7.2 & 80.2 & 22.8 & 4.1 & 61.4 & 16.4 \\
\hline $\begin{array}{l}\text { Stocking } \\
\text { density }\end{array}$ & $\mathrm{LU} / \mathrm{ha}$ & 0.05 & 1.17 & 0.62 & 0.04 & 1.55 & 0.97 \\
\hline
\end{tabular}

Source: as in Table 2.

As it was expected, farms from municipalities with a high share of LFA specific type zone I had lower wheat and maize yields as well as lower milk yields of cows as compared to similar farms in other municipalities (Table 4). In the case of wheat yields, the difference to their disadvantage was particularly noticeable in the case of farms with dairy cows (37.9\%), in the case of farms with field crops $(29.7 \%)$ it was noticeable to a smaller extent, and in the case of farms with diversified production $(25.1 \%)$ to the smallest extent. As far as the maize yields are concerned, the largest difference was observed in farms with dairy cows $(26.5 \%)$, followed by the diversified production (14.4\%) and field crops $(8.5 \%)$. On the other hand, in the case of milk yields of cows, a larger difference was noticed in farms with diversified production $(24.3 \%)$ and a smaller one with dairy cows $(4.2 \%)$. As far as farms with field crops are concerned, the farming of dairy cows did not occur (Table 4).

Table 4

Production effects of the analysed farms located in municipalities with a high share of LFA specific type zone I and in non-LFA municipalities which differ in terms of production type in 2016-2018

\begin{tabular}{lccccccc}
\hline & & \multicolumn{6}{c}{ Gospodarstwa } \\
\cline { 3 - 8 } Variable & Unit & \multicolumn{2}{c}{$\begin{array}{c}\text { in municipalities with at least 80\% of LFA } \\
\text { specific type zone I in UAA }\end{array}$} & \multicolumn{2}{c}{ in non-LFA municipalities } \\
\cline { 3 - 8 } & & $\begin{array}{c}\text { with field } \\
\text { crops }\end{array}$ & $\begin{array}{c}\text { with dairy } \\
\text { cows }\end{array}$ & $\begin{array}{c}\text { with } \\
\text { diversified } \\
\text { production }\end{array}$ & $\begin{array}{c}\text { with field } \\
\text { crops }\end{array}$ & $\begin{array}{c}\text { with dairy } \\
\text { cows }\end{array}$ & $\begin{array}{c}\text { with } \\
\text { diversified } \\
\text { production }\end{array}$ \\
\hline Wheat yield & $\mathrm{dt} / \mathrm{ha}$ & 42.4 & 32.4 & 42.4 & 60.3 & 52.2 & 56.6 \\
Maize yield & $\mathrm{dt} / \mathrm{ha}$ & 70.6 & 46.6 & 61.7 & 77.2 & 63.4 & 72.1 \\
$\begin{array}{l}\text { Milk yield } \\
\text { of cows }\end{array}$ & $\begin{array}{c}\mathrm{kg} / \mathrm{cow} / \\
\text { year }\end{array}$ & - & 6055.0 & 3039.0 & - & 6323.5 & 4014.1 \\
\hline
\end{tabular}

Source: as in Table 2. 
Compared to other similar farms, farms from municipalities with a high share of LFA specific type zone I incurred lower total costs per 1 ha of UAA from 18.0 to $37.8 \%$, including lower indirect and general economic costs from 23.8 to $42.6 \%$ and from 2.2 to $28.4 \%$, respectively (Table 5). It should be noted, however, that farms with field crops located in municipalities with a high share of LFA specific type zone I, as compared to other similar economic areas, incurred slightly higher energy costs, including fuels per 1 ha of UAA. It is likely that one of the reasons for the situation in these farms was a broader distribution, smaller size and unfavourable shape of the fields as well as difficult access to them caused by a high share of valuable natural areas, including forests and inland waters, which is also reflected in the higher human labour input incurred in the production process (Tables 2 and 5).

Table 5

Costs and cost structure of the analysed farms located in municipalities with a high share of LFA specific type zone I and in non-LFA municipalities which differ in terms of production type in 2016-2018

\begin{tabular}{|c|c|c|c|c|c|c|c|}
\hline \multirow{3}{*}{ Variable } & \multirow{3}{*}{ Unit } & \multicolumn{6}{|c|}{ Farms } \\
\hline & & \multicolumn{3}{|c|}{$\begin{array}{l}\text { in municipalities with at least } 80 \% \\
\text { of LFA specific type zone I in UAA }\end{array}$} & \multicolumn{3}{|c|}{ in non-LFA municipalities } \\
\hline & & $\begin{array}{l}\text { with field } \\
\text { crops }\end{array}$ & $\begin{array}{l}\text { with dairy } \\
\text { cows }\end{array}$ & $\begin{array}{c}\text { with } \\
\text { diversified } \\
\text { production }\end{array}$ & $\begin{array}{l}\text { with field } \\
\text { crops }\end{array}$ & $\begin{array}{l}\text { with dairy } \\
\text { cows }\end{array}$ & $\begin{array}{c}\text { with } \\
\text { diversified } \\
\text { production }\end{array}$ \\
\hline Total costs & $\begin{array}{l}\text { PLN } \\
\text { thousand/ha }\end{array}$ & 3.33 & 5.28 & 4.12 & 4.06 & 8.49 & 6.11 \\
\hline $\begin{array}{l}\text { - including } \\
\text { direct costs }\end{array}$ & $\begin{array}{l}\text { PLN } \\
\text { thousand/ha }\end{array}$ & 1.47 & 2.65 & 2.18 & 1.93 & 4.62 & 3.54 \\
\hline $\begin{array}{l}\text { - including the } \\
\text { cost of seeds } \\
\text { and seedlings }\end{array}$ & $\begin{array}{l}\text { PLN } \\
\text { thousand/ha }\end{array}$ & 0.26 & 0.12 & 0.19 & 0.35 & 0.26 & 0.26 \\
\hline $\begin{array}{l}\text { - including costs } \\
\text { of mineral } \\
\text { fertilisers }\end{array}$ & $\begin{array}{c}\text { PLN } \\
\text { thousand/ } \\
\text { ha }\end{array}$ & 0.68 & 0.50 & 0.54 & 0.95 & 0.60 & 0.77 \\
\hline $\begin{array}{l}\text { - including the } \\
\text { costs of plant } \\
\text { protection } \\
\text { products }\end{array}$ & $\begin{array}{l}\text { PLN } \\
\text { thousand/ha }\end{array}$ & 0.28 & 0.05 & 0.20 & 0.48 & 0.20 & 0.34 \\
\hline $\begin{array}{l}\text { Farming } \\
\text { overheads }\end{array}$ & $\begin{array}{l}\text { PLN } \\
\text { thousand/ha }\end{array}$ & 0.90 & 1.26 & 0.91 & 0.92 & 1.76 & 1.19 \\
\hline $\begin{array}{l}\text { - including } \\
\text { energy costs }\end{array}$ & $\begin{array}{l}\text { PLN } \\
\text { thousand/ha }\end{array}$ & 0.46 & 0.52 & 0.48 & 0.43 & 0.73 & 0.49 \\
\hline
\end{tabular}

Source: as in Table 2.

Poorer production results in the case of farms located in municipalities with a high share of LFA specific type zone I , compared to those operating under more favourable conditions, were reflected in lower productivity of production factors. The greatest difference to the disadvantage of farms located in LFA in terms of land productivity was observed in the case of farms with dairy cows $(30.6 \%)$, and labour productivity in farms with field crops (30.1\%) (Table 6). 
Farms located in municipalities with a high share of LFA specific type zone I, compared to other similar farms, had lower income per 1 ha of UAA and per 1 FWU within the limits of $4.7-27.3 \%$ and $6.0-33.5 \%$, respectively. It should be noted, however, that in the case of all the analysed groups of farms located in LFA municipalities and non-LFA municipalities, the income per 1 FWU was higher than the average parity income in the national economy in between 2016 and 2018 (PLN 34.5 thousand) (Abramczuk, Augustyńska, Bębenista and Żekało, 2018; Abramczuk and Skarżyńska, 2018; Abramczuk, Augustyńska and Bębenista, 2019). Nevertheless, farms with field crops and dairy cows located in municipalities with LFA specific type zone I in comparison with similar farms from other municipalities did not fully reproduce the fixed assets used in production. This is indicated by their negative net investment rate. In this respect, farms with diversified production located in LFA, which were able to increase the value of their fixed assets, also using foreign resources to a small extent, were in a more favourable situation. It is worth noting that farms located in non-LFA municipalities, fully recovering the fixed assets used in the production process and making greater use of foreign assets for this purpose, were in a much better position in terms of the net investment rate obtained (Table 6).

Table 6

Productivity, economic situation and development possibilities of the analysed farms located in municipalities with a high share of LFA specific type zone I and in non-LFA municipalities which differ in terms of production type in 2016-2018

\begin{tabular}{lccccccc}
\hline & & \multicolumn{6}{c}{ Farms } \\
\cline { 3 - 7 } \multicolumn{1}{c}{ Variable } & Unit & $\begin{array}{c}\text { in municipalities with at least 80\% of } \\
\text { LFA specific type zone I in UAA }\end{array}$ & in non-LFA municipalities \\
\cline { 3 - 8 } & & $\begin{array}{c}\text { with field } \\
\text { crops }\end{array}$ & $\begin{array}{c}\text { with dairy } \\
\text { cows }\end{array}$ & $\begin{array}{c}\text { with } \\
\text { diversified } \\
\text { production }\end{array}$ & $\begin{array}{c}\text { with field } \\
\text { crops }\end{array}$ & $\begin{array}{c}\text { with dairy } \\
\text { cows }\end{array}$ & $\begin{array}{c}\text { with } \\
\text { diversified } \\
\text { production }\end{array}$ \\
\hline $\begin{array}{l}\text { Land } \\
\text { productivity }\end{array}$ & $\begin{array}{c}\text { PLN } \\
\text { thousand/ha }\end{array}$ & 3.6 & 7.7 & 6.0 & 5.1 & 11.1 & 7.5 \\
$\begin{array}{l}\text { Labour } \\
\text { efficiency }\end{array}$ & $\begin{array}{c}\text { PLN thousand/ } \\
\text { FWU }\end{array}$ & 104.0 & 130.5 & 115.5 & 148.8 & 167.4 & 132.9 \\
$\begin{array}{l}\text { Income } \\
\text { per farm }\end{array}$ & $\begin{array}{c}\text { PLN } \\
\text { thousand/ha }\end{array}$ & 1.6 & 4.1 & 2.2 & 2.2 & 4.3 & 2.8 \\
$\begin{array}{l}\text { Income from } \\
\text { own labour }\end{array}$ & $\begin{array}{c}\text { PLN thousand/ } \\
\text { FWU }\end{array}$ & 52.3 & 69.1 & 52.2 & 78.6 & 73.5 & 57.1 \\
$\begin{array}{l}\text { Net investment } \\
\text { rate }\end{array}$ & $\%$ & -42.2 & -4.2 & 5.5 & 0.2 & 49.7 & 11.3 \\
\begin{tabular}{l} 
Debt ratio \\
\hline
\end{tabular} & $\%$ & 12.6 & 17.2 & 11.5 & 23.5 & 22.7 & 19.2 \\
\hline
\end{tabular}

Source: as in Table 2. 


\section{Summary and conclusions}

In the first place, the study describes the method of determining LFA specific type zone I developed by IUNG-PIB in Puławy and commissioned by the MRiRW and the EC. These areas were determined on the basis of the threshold value of the Nature and Tourism Index (WCPT) and the value of agricultural production space (WWRPP). It should also be emphasised that in Poland the range of these areas has been valid since 2019. The next stage of the research was to evaluate the functioning of farms located in municipalities with a high share of LFA specific type zone I (at least $80 \%$ of LFA zone specific type I in UAA) in comparison with similar farms located in non-LFA municipalities. The analysis covered farms that kept accounts for the Polish FADN continuously in 2016-2018. Among farms located in municipalities with a high share of LFA specific type zone I 79 and 589 farms with field crops (type 1), 59 and 89 farms with dairy cows (type 45), and 42 and 272 farms with diversified production (type 8) were distinguished, respectively. Their production potential, production organisation, costs, production effects, economic situation and development possibilities were analysed.

It was established that:

- in Poland, LFA specific type zone I include 1,233.7 thousand ha of UAA, i.e. $11.8 \%$ of the total LFA UAA and $7.0 \%$ of the national UAA. These areas are located in 600 municipalities with an average WCPT index of 37.9 points (the national average is 35.6 points out of 100 points possible), an average UAA of 8.5 thousand ha and an average area of farms of 13.2 ha of UAA. It should also be added that in 36 municipalities, the share of these areas equals at least $80 \%$ of UAA, and their average WCPT index is 48.6 points;

- the analysed farms located in municipalities with a high share of LFA specific type zone I, compared to similar farms from non-LFA municipalities were characterised by a significantly lower quality of UAA owned, higher age of their managers, as well as lower capital value, including the value of machinery and equipment owned, which co-determined their worse technical equipment. Moreover, they had a higher share of fodder crops in UAA, but a lower livestock density. They were characterised by lower production intensity and, as a result, lower productivity of production factors. Despite lower production intensity, they incurred comparable overall economic costs, and in the case of farms with field crops, they incurred even higher energy costs, including fuels. However, these farms obtained lower income per 1 ha of UAA and 1 HUF. Nonetheless, the income per $1 \mathrm{FWU}$ was so high that in each analysed farm group it was sufficient to cover the labour costs of the owner and his family members at a higher level than the average salary in the national economy. Nevertheless, in the case of farms with field crops and dairy cows from areas with a high share of LFA specific type zone I, the income did not allow them to fully reproduce the fixed assets used in the production process. This is indicated by their negative net investment rate. The situation was slightly better in the case of farms with 
diversified production where there was a positive net investment rate, although they were also at a disadvantage in this respect compared to other similar farms. It should also be mentioned that farms in areas with a high share of LFA specific type zone I benefited less from foreign resources, which also proves a lower investment activity.

The analysis based on data from the Polish FADN for 2016-2018 showed that the farms located in municipalities with a high share of LFA specific type zone I were in a worse economic situation compared to farms which served as a reference point, and as a result, had fewer opportunities for development. However, it should be noted that in this area, it is possible to conduct agricultural production provided that both production and farms are organised properly. 


\section{References}

Abramczuk, Ł., Augustyńska, I., Bębenista, A., Żekało, M. (2018). Produkcja, koszty i dochody $z$ wybranych produktów rolniczych w latach 2016-2017 (wyniki rachunku symulacyjnego). Warszawa: IERiGŻ-PIB.

Abramczuk, Ł., Skarżyńska, A. (2018). Wyniki ekonomiczne wybranych produktów rolniczych w 2017 roku. Warszawa: IERiGŻ-PIB.

Abramczuk, Ł., Augustyńska, I., Bębenista, A. (2019). Produkcja, koszty i dochody z wybranych produktów rolniczych w latach 2017-2018 (wyniki rachunku symulacyjnego). Warszawa: IERiGŻ-PIB.

Baza danych użytkowania gruntów w Polsce w ujęciu regionalnym. IUNG-PIB (access date: 20.04.2017).

Baza danych gospodarstw rolnych beneficjentów płatności obszarowych w 2017 r. (stan na 31.12.2017 r.). ARiMR (access date: 27.11.2018).

Dudzińska, M. (2011). Czynniki oceniające rolniczą przestrzeń produkcyjną. Infrastruktura i Ekologia Terenów Wiejskich, No. 1, pp. 173-184.

European Comission (2016).Fine-Tuning in Areas Facing Significant Natural and Specific Constraints. No. 7/2016.

GUS (2013). Rolnictwo na obszarach specyficznych. Powszechny Spis Rolny 2010. Warszawa: GUS.

GUS (2017). Charakterystyka gospodarstw rolnych w $2016 r$. Warszawa: GUS.

Informacja o nowej delinitacji ONW, MRiRW (2018). Retrieved from: https://www.gov.pl/web/ rolnictwo/delimitacja-onw-wedlug-nowych-zasad-ue.

Joint Research Centre (2016). Updated Guidelines for Applying Common Criteria to Identify Agricultural Areas with Natural Constraints.

Juroszek, Z. (2011). Wpływ lokalnych uwarunkowań na koszty jednostkowe pozyskania paliw odnawialnych. Polityka Energetyczna, Vol. 14, Issue 1, pp. 179-196.

Kołodziejczak, A., Głębocki, B., Kacprzak, E., Maćkiewicz, B., Szczepańska, M. (2018). Społeczne i ekonomiczne koszty bezładu przestrzennego w rolnictwie. Studia KPZK, Vol. 182(2), pp. 239-279.

Łopatka, A., Koza, P., Siebielec, G. (2017). Propozycja metodyki wydzieleń zasięgów obszarów ONW typ specyficzny wg tzw. kryteriów krajowych. IUNG-PIB.

Opis $i$ wyniki zastosowania procedury zawężania wyboru do obszarów z ograniczeniami naturalnymi (ang. fine-tuning) w Polsce (2017). Warszawa: MRiRW, IERiGŻ-PIB.

Prishchepov, A.V., Müller, D., Dubinin, M., Baumann, M., Radeloff V.C. (2013). Determinants of Agricultural Land Abandonment in Post-Soviet European Russia. Land Use Policy, Vol. 30, pp. 873-884. DOI:10.1016/j.landusepol.2012.06.011.

Program Rozwoju Obszarów Wiejskich 2014-2020 (2018). Warszawa: MRiRW.

Raport techniczny przedstawiający metodologię stosowana do wyznaczenia obszarów z ograniczeniami naturalnymi $w$ Polsce $w$ oparciu o kryteria biofizyczne (2018). Warszawa: MRiRW, IUNG-PIB.

Regulation (EU) No. 1305/2013 of the European Parliament and of the Council of 17 December 2013 on support for rural development by the European Agricultural Fund for Rural Development (EAFRD) and repealing Council Regulation (EC) No. 1698/2005.

Wstępna koncepcja wyznaczania na obszarach wiejskich Polski obszarów o wysokich walorach przyrodniczych (HNV) oraz opracowanie dla nich programu monitoringu (2009). Puławy: IUNG-PIB, IERiGŻ-PIB, ITP, IGiK, CIoŚ. 
Wyniki standardowe 2018 uzyskane przez gospodarstwa rolne uczestniczace w Polskim FADN. Część I. Wyniki standardowe (2019). Warszawa: IERiGŻ-PIB.

Zieliński, M. (2019). Prace przeprowadzone w IERiGŻ-PIB nad wyznaczeniem obszarów ONW z ograniczeniami naturalnymi w Polsce po 2018 r. Presentation delivered at IERiGŻ-PIB on 23 August 2018 during a meeting with representatives of the Embassy of France.

Zieliński, M., Sobierajewska, J. (2020). Gospodarstwa rolne z obszarów o dużej cenności przyrodniczej w Polsce. Presentation delivered at IERiGŻ-PIB on 14 February 2020. 


\title{
OCENA FUNKCJONOWANIA GOSPODARSTW NA OBSZARACH O NIEKORZYSTNYCH WARUNKACH GOSPODAROWANIA I DUŻEJ CENNOŚCI PRZYRODNICZEJ (ONW TYP SPECYFICZNY STREFA I)
}

\begin{abstract}
Abstrakt
Celem tego opracowania jest charakterystyka gmin o dużym nasyceniu ONW typ specyficzny strefa I oraz ocena funkcjonowania gospodarstw rolnych z tych gmin, na tle analogicznych gospodarstw z gmin spoza ONW, które prowadzity nieprzerwanie rachunkowość dla Polskiego FADN w latach 2016-2018. W pierwszej czéści opracowania dokonano opisu metody wyznaczania oraz charakterystyki obszarów z ograniczeniami naturalnymi (ONW) typ specyficzny strefa I w Polsce, które Instytut Uprawy Nawożenia i Gleboznawstwa - PIB w Puławach (IUNG-PIB) wyznaczyt na zlecenie Ministerstwa Rolnictwa i Rozwoju Wsi (MRiRW) oraz Komisji Europejskiej (KE), w oparciu o wartości progowe wskaźnika waloryzacji rolniczej przestrzeni produkcyjnej (WWRPP) i opracowanego $w$ tym celu wskaźnika cenności przyrodniczo-turystycznej (WCPT). Obszary te obowiąuja w naszym kraju od 2019 r. i obejmuja 1233,7 tys. ha UR. W drugiej części opracowania dokonano oceny funkcjonowania gospodarstw rolnych z gmin o dużym nasyceniu ONW typ specyficzny strefa I (co najmniej 80\% UR ONW typ specyficzny strefa I $w$ powierzchni UR $w$ gminie) na tle analogicznych gospodarstw z gmin spoza ONW, które prowadzity nieprzerwanie rachunkowość dla Polskiego FADN w latach 2016-2018. Ustalono, że gospodarstwa z gmin z ONW typ specyficzny strefa I na tle gospodarstw bęacych punktem odniesienia charakteryzują się m.in. mniejsza wartościa kapitatu, wyższym wiekiem ich kierowników oraz gorsza jakością użytkowanych gleb. Ponadto mają niższe produktywności czynników produkcji oraz mniejszy dochód w przeliczeniu na 1 ha UR i na 1 FWU, co ogranicza ich możliwości rozwoju.
\end{abstract}

Słowa kluczowe: ONW typ specyficzny strefa I, cenność przyrodnicza, gospodarstwo rolne, potencjał produkcyjny, sytuacja ekonomiczna.

Accepted for print: 28.09.2020.

Unless stated otherwise all the materials on the website are available under the Creative Commons Attribution 4.0 International license.

Some rights reserved to the Institute of Agricultural and Food Economics - National Research Institute.

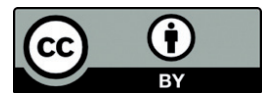

